\title{
PENURUNAN TINGKAT KEBISINGAN RUANG KERJA MELALUI OPTIMALISASI FUNGSI JENDELA KACA PADA GEDUNG ADMINISTRASI BANDAR UDARA STUDI KASUS DI BANDAR UDARA JUANDA SURABAYA
}

\author{
Sigit Widodo, M. Nawawiy Loebis, Basaria Talarosha \\ Program Studi Magister Teknik Arsitektur Fakultas Teknik Universitas Sumatera Utara \\ Jl. Perpustakaan St. J07 Building, Medan, 20155, Indonesia \\ Email: sigitwdd7@gmail.com
}

\begin{abstract}
ABSTRAK
Kawasan bandar udara merupakan kawasan yang memiliki intensitas kebisingan yang sangat tinggi bahkan terus meningkat seiring dengan bertambahnya frekwensi lalu lintas udara. Intensitas Kebisingan yang umumnya dikeluhkan oleh sejumlah pekerja di bandar udara adalah tidak bisa berkonsentrasi dan sering melakukan kesalahan dalam melaksanakan pekerjaan. Permasalahan ini dikarenakan pada umumnya gedung fasilitas di beberapa Bandar udara dengan elemen bukaan bangunan seperti jendela kaca, tidak memiliki kemampuan dalam hal mereduksi intensitas bunyi yang berlebih. Gangguan kebisingan seperti ini juga terjadi di Bandar Udara Juanda Surabaya yang termasuk bandar udara terbesar dan tersibuk kedua setelah Bandar udara Internasional Soekarno Hatta Jakarta.

Keberadaan landas pacu di bandar udara yang berfungsi sebagai fasilitas mendarat dan tinggal landas pesawat terbang merupakan sumber utama kebisingan dengan intensitas bunyi antara 125-140 dB, sementara nilai standar faktor tempat kerja yang dapat diterima tenaga kerja terkait faktor kesehatan dan kenyamanan pada umumnya berkisar 65-85 dB.

Berdasarkan hasil penilitian, Pemanfaatan sistem kaca ganda dapat menaikkan nilai insulasi lebih dari $30 \%$, dengan rincian kaca ganda minimal 2x6mm pada unit jendela mampu mereduksi bunyi sampai $\leq 65$ dB, sistem ini jauh lebih efisien jika dibandingkan dengan memperbesar dimensi atau ketebalan kaca ataupun memodifikasi jarak gedung dari sumber bising. Upaya selanjutnya adalah perletakan posisi panil kaca atau unit jendela kaca pada sudut $15^{\circ}$ terhadap posisi normal, serta pemilihan material yang memiliki nilai negatif terhadap faktor penghantar getaran bunyi seperti kayu dan PVC, material tersebut cukup baik untuk dimanfaatkan sebagai material penyusun struktur (frame) unit jendela kaca karena dapat meminimalisir efek getaran bunyi yang akan merambat dari bagian luar gedung.
\end{abstract}

Kata Kunci: Kawasan Bandar Udara Juanda Surabaya, Intensitas Kebisingan, Jendela Kaca.

\section{PENDAHULUAN}

Kemajuan teknologi adalah satu hal yang tidak bisa dihindari dalam kehidupan manusia saat ini, namun dari kemajuan teknologi yang telah terbukti memberi banyak kemanfaatan tersebut, manusia tidak bisa menutup mata bahwa pada kenyataannya teknologi pun mendatangkan berbagai efek negative termasuk dalam dunia penerbangan, pertumbuhan jumlah produksi pesawat terbang dan frekuensi penerbangan yang semakin meningkat pada tiap tahunnya akan memberi dampak langsung pada peningkatan emisi polutan dan kebisingan pesawat terbang di lingkungan bandar udara dan sekitarnya.
Keberadaan landas pacu di bandar udara yang berfungsi sebagai fasilitas mendarat dan tinggal landas pesawat terbang merupakan area utama sumber kebisingan, Davis (2008) menjelaskan bahwa jet take-off pada jarak 100 meter akan menghasilkan kekuatan bunyi 125 $\mathrm{dB}$ dan sebuah jet engine pada jarak 25 meter akan menghasilkan kekuatan bunyi $140 \mathrm{~dB}$, sementara nilai ambang batas atau standar faktor tempat kerja yang dapat diterima tenaga kerja tanpa mengakibatkan penyakit atau gangguan kesehatan dalam pekerjaan sehari-hari untuk waktu tidak melebihi 8 jam sehari atau 40 jam seminggu adalah $85 \mathrm{~dB}$ seperti dinyatakan oleh Idris (1999) dan baku mutu kebisingan untuk

Edisi cetak 
perkatoran atau ruang kerja pada umumnya 65 dB (Kusumaatmadja,1996).

Bunyi terjadi dari tiga unsur dasar yaitu muncul dari sumber bunyi, merambat melalui jalur dan mempengaruhi penerima atau pendengar (Cornwell, 1997), kebisingan bandar udara yang bersumber dari mesin pesawat terbang merambat melalui media udara menuju gedung hingga menembus dinding dan jendela untuk kemudian diterima pendengar yaitu karyawan di ruang kerja, dengan pertimbangan bahwa jendela merupakan satu bentuk bukaan dalam gedung yang sekaligus merupakan faktor perlemahan dalam hal pengendalian kebisingan gedung, maka perencanaan optimalisasi fungsi jendela kaca merupakan satu solusi dalam rangka mereduksi kebisingan pada sejumlah gedung di lingkungan bandar udara, sehingga dampak kebisingan pesawat terbang dapat berkurang baik pada ruang dalam maupun pada lingkungan gedung.

Metodologi yang digunakan dalam penelitian ini antara lain Pengukuran, Rancangan Awal, Pengujian, serta Rekomendasi desain. Pengukuran atau survei lapangan digunakan untuk memperoleh data variabel penelitian yang berupa data bangunan dan lingkungan yang terkait objek rambatan bunyi dan sumber kebisingan, berdasarkan data hasil survei dan kajian pustaka yang ada dapat dilakukan analisa guna penyusunan rancangan awal atau pemodelan desain unit jendela kaca dengan memperhitungkan pencapaian kondisi kenyamanan ruang kerja pada gedung administrasi di bandar udara dilihat dari faktor intensitas bunyi, dari konsep pemodelan desain unit jendela kaca tersebut selanjutnya akan di uji dengan memanfaatkan perhitungan matematis dari N.K. Garg (2007) sehingga akan diperoleh nilai intensitas kebisingannya yang menunjukkan kemampuan objek rancangan tersebut yang selanjutnya dapat ditarik kesimpulan dalam bentuk rekomendasi dan konsep desain.

\section{TINJAUAN PUSTAKA}

Doelle (1972) menyatakan bahwa secara fisis bunyi dapat didefinisikan sebagai penyimpangan tekanan, pergeseran partikel dalam medium elastik seperti udara dan sering disebut bunyi obyektif, sementara secara fisiologis bunyi adalah sensasi pendengaran yang disebabkan penyimpangan fisis dan sering disebut sebagai bunyi subyektif. Secara fisik tidak ada perbedaan antara bunyi dengan bising, bunyi pada dasarnya merupakan persepsi sensori dari pola kompleks dari getaran bunyi yang dapat dilabeli sebagai percakapan, musik ataupun kebisingan. Intensitas suara merupakan sensasi berupa kekerasan suara yang dirasakan manusia, suatu energi atau tenaga per satuan luas (contoh Newton per meter persegi $\mathrm{N} / \mathrm{m}^{2}$ ) sering disebut Intensitas Suara dan satuan dasar yang digunakan adalah Bel (B), ataupun masyarakat lebih umum menggunakan satuan decibel (dB) dimana $1 \mathrm{~dB}=0,1 \mathrm{~B}$ (Suma'mur, 1996). Bising dapat didefinisikan sebagai bunyi yang mengalihkan perhatian, berlebihan, mengganggu atau berbahaya bagi kegiatan sehari hari ataupun kesehatan manusia sebagaimana dinyatakan oleh Norman Ashford (1992). Horojeff (2009) menyatakan bahwa kebisingan dapat dikontrol atau dikendalikan dengan cara pengendalian pada sumber bising, meningkatkan jarak antar sumber bising, mengurangi waktu paparan bising, menempatkan barrier atau penghalang dan pemanfaatan alat pelindung telinga atau earmuff - earplug, sementara Mackenzie Davis (1999) berpendapat bahwa faktor yang mempengaruhi ambang batas pendengaran adalah level suara, distribusi frekwensi suara, durasi suara, distribusi kepaparan suara sementara, perbedaan individual dalam toleransi suara dan tipe suara. Terkait bunyi maka Snellius (2010) melalui hukum pembiasannya menjelaskan bahwa bunyi datang, garis normal, dan bunyi pantul terletak pada satu bidang datar.

Dalam hal pengendalian bising pada bangunan, N.K. Garg (2007) secara umum menjelaskan melalui perhitungan matematis dengan satuan decibel (dB), yaitu:

1. Modified Noise Level (MNL), merupakan perhitungan tekanan bunyi di sekitar bangunan dengan satuan perhitungan decibel $(\mathrm{dB})$.

$(\mathrm{MNL})=\mathrm{NLS}-20 \log 10 \mathrm{r}-10.9$

$(\mathrm{NLS})=$ Noise Level At Source

$(\mathrm{r})=$ Distance of The Building

2. Inside Noise Level (INL), merupakan perhitungan tekanan bunyi di dalam bangunan dengan satuan perhitungan decibel $(\mathrm{dB})$.

$(\mathrm{INL})=\mathrm{ANL}-\mathrm{Rw}+\log 10 \mathrm{~s}$

$(\mathrm{Rw})=$ Noise Reduction Index 


\section{$(\mathrm{s})=$ Area of Glass}

Dalam perhitungan diatas maka faktorfaktor yang akan mempengaruhi tekanan suara atau kebisingan di dalam bangunan adalah besar bising sumber, jarak transmisi bunyi, barier atau penghalang antar sumber bunyi dan bangunan dan jenis serta dimensi material pemisah ruang luar dan dalam bangunan

Menurut Peraturan Pemerintah No 40 Tahun 2012 mengenai Pembangunan dan Pelestarian Lingkungan Hindup Bandar Udara, kawasan kebisingan didefinisikan sebagai kawasan tertentu di sekitar bandar udara yang terpengaruh gelombang suara mesin pesawat udara yang terdiri atas kebisingan tingkat I, kebisingan tingkat II dan kebisingan tingkat III. Ambang batas kebisingan di bandar udara dan sekitarnya ditentukan dengan indek kebisingan WECPNL (Weighted Equivalent Continuous Perceived Noise Level) atau nilai equivalen tingkat kebisingan di suatu area yang dapat diterima terus menerus selama suatu rentang waktu dengan pembobotan tertentu. Untuk alasan kenyamanan maka suatu gedung diharapkan dapat mengisolasi suara yang datang dari lingkungan sekelilingnya, terlebih pada gedung-gedung perkantoran di lingkungan dengan tingkat kebisingan yang tinggi seperti bandar udara (N.K. Garg, 2007). Telah diketahui bahwa indek kebisingan pesawat udara di lingkungan bandar udara pada umumnya berada pada tingkat III skala WECPNL dengan konsekwensi pemanfaatan lahannya hanya untuk membangun fasilitas bandar udara seperti gedung yang dilengkapi insulasi suara (Yudhoyono, 2012).

Sejumlah penelitian mengenai tingkat intensitas bunyi ataupun kebisingan di sekitar kawasan bandar udara sudah banyak dilakukan, tetapi pada umumnya fokus yang dilakukan adalah lebih banyak pada pemetaan kebisingan sisi udara bandar udara dan kawasan sekitar bandar udara atau lingkungan masyarakat. Penelitain penelitian tersebut diantaranya dilakukan oleh Y.A. Wulur (2014) melakukan penelitian kebisingan di Bandar udara Sam Ratulangi Manado, Evi dan sejumlah rekanrekannya (2013) melakukan penelitian kebisingan di Bandar udara Ahmad Yani Semarang, M.Chaeran (2008) melakukan penelitian kebisingan di Bandar udara Ahmad Yani Semarang, P.Miroslov dan sejumlah rekanrekannya (2013) melakukan penelitian di Bandar udara Sultan Hasanuddin makassar.

\section{FASILITAS DAN OPERASIONAL BANDAR UDARA}

Secara umum bandar udara dapat didefinisikan sebagai sebuah kawasan di daratan atau perairan dengan batas-batas tertentu yang berfungsi sebagai tempat lepas landas (take-off) dan mendaratnya (landing-off) pesawat terbang yang dilengkapi dengan fasilitas pendukung operasional penerbangan. Fasilitas pokok bandar udara meliput: fasilitas sisi darat, fasilitas sisi udara, fasilitas navigasi penerbangan, fasilitas alat bantu pendaratan visual, dan fasilitas komunikasi penerbangan, sedangkan fasilitas pendukung dapat berupa fasilitas penginapan atau hotel, fasilitas pertokoan atau restauran, fasilitas penempatan kendaaan bermotor, fasilitas perawatan dan lain sebagainnya. Keberadaan runway atau landas pacu merupakan syarat minimal suatu bandar udara, merupakan bagian dari fasilitas sisi udara disamping apron dan taxiway yang berfungsi sebagai tempat mendarat dan tinggal landas pesawat terbang. Terminal penumpang merupakan fasilitas utama sisi darat bandar udara, berfungsi untuk memproses kedatangan dan keberangkatan penumpang termasuk bagasi penumpang dari dan menuju pesawat terbang. Penentuan kebutuhan luas terminal penumpang mengacu pada jumlah penumpang dan jenis pesawat yang akan dilayani, sedangkan fasilitas parkir kendaraan merupakan sarana pendukung terminal penumpang dan termasuk dalam kelengkapan fasilitas darat lainnya adalah sejumlah gedung perkantoran yang diperuntukan sebagai gedung layanan administrasi dan operasional bandar udara.

Aktifitas atau operasional pesawat terbang di kawasan bandar udara dimulai dari proses pendekatan ke lokasi bandar udara atau approach yang dilanjutkan dengan proses pendaratan pesawat atau landing-off di runway, serta proses taxi menuju apron hingga pesawat berhenti dan siap menurunkan atau menaikan penumpang dan bagasi di depan terminal penumpang, demikian prosedur sebaliknya ketika pesawat akan meninggalkan bandar udara (Gambar 1). 


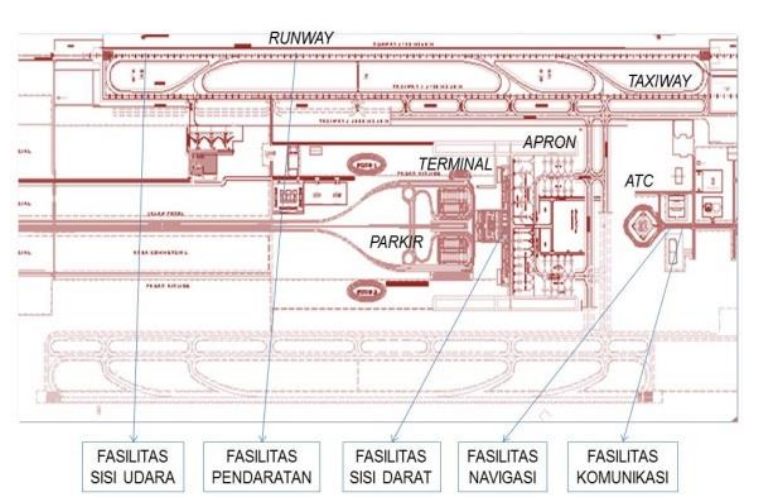

Gambar 1. Fasilitas Bandar Udara

Sumber: Ditjen. Perhubungan Udara, 2005

Bandar Udara Juanda Surabaya adalah bandar udara terbesar dan tersibuk kedua berdasarkan pergerakan pesawat dan penumpang, dikelompokan dalam bandar udara kelas 1 yang sekaligus berstatus sebagai bandar udara internasional utama, bandar udara internasional regional dan bandar udara internasional penerbangan haji (Mangindaan, 2013). Bandar udara ini dikelola oleh Angkasa Pura Airports bersama dengan 12 bandar udara lainnya sebagai salah satu Badan Usaha Milik Negera (BUMN) sektor perhubungan yang bergerak dalam bidang pengelolaan dan pengusahaan jasa kebandarudaraan, sebagai entitas bisnis milik negara maka tujuan utama Angkasa Pura Airports adalah mendukung kebijakan dan program pemerintah di bidang ekonomi dan penerbangan (Tabel 1).

Tabel 1. Perkembangan Lalu Lintas Udara Bandar Udara Juanda

\begin{tabular}{llccc}
\hline & & \multicolumn{3}{c}{$\begin{array}{c}\text { Peningkatan Pergerakan lalu Lintas } \\
\text { (Jumlah Penumpang/Pesawat/Ton) }\end{array}$} \\
& & $(\%)$ & Tahun 2013 & Tahun 2009 \\
\hline 1 & Penumpang & 66 & 139.668 .676 & 84.285 .105 \\
2 & Pesawat & 36 & 1.248 .905 & 918.016 \\
3 & Kargo, & 15 & 1.741 .145 .821 & 1.512 .924 .691 \\
& Bagasi dan & & & \\
& Pos & & & \\
\hline
\end{tabular}

Sumber: Kemenhub, 2014

Dengan panjang runway $3000 \mathrm{~m} \times 45$ $\mathrm{m}$ dan apron $158.606 \mathrm{~m}^{2}$ serta dilengkapi 9 taxiway, Bandar udara Juanda saat ini mampu menampung rata-rata 366 pergerakan pesawat tinggal landas dan mendarat dalam tiap harinya, fasilitas lainnya yang saat ini dalam proses pengembangan adalah gedung terminal penumpang sehingga total luas menjadi 112.200 $\mathrm{m}^{2}$ untuk menampung 14 juta penumpang (Gambar 2).

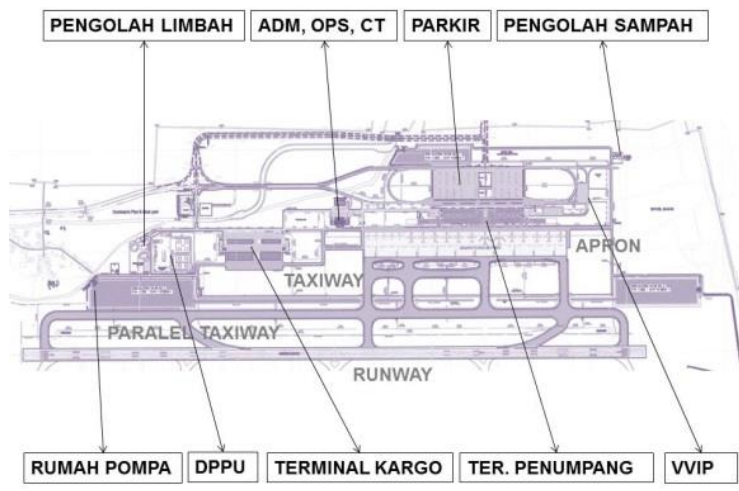

Gambar 2. Fasilitas Sisi Udara dan Sisi Darat Bandar udara Juanda Surabaya

Sumber: Departemen Perhubungan, 2007

Spesifikasi gedung perkantoran di bandar udara umumnya masih mengacu pada standar kontruski gedung pemerintah yang mengutamakan kemanfaatan dan keselamatan, hemat dan tidak berlebihan, terarah dan terkendali serta semaksimal mungkin menggunakan produk dalam negeri. Sebagai gambaran sistem struktur yang diterapkan pada gedung perkantoran adalah konstruksi beton bertulang dengan rangka kaku atau rigid frame, jumlah lantai hanya terbatas satu sampai tiga lantai yang mengacu peraturan batas ketinggian bangunan (obstacle) di lingkungan operasional bandar udara.

\section{DAMPAK KEBISINGAN OPERASIONAL PESAWAT TERBANG}

Batas kawasan kebisingan bandar udara merupakan zona tertentu di sekitar bandar udara yang terpengaruh gelombang suara mesin pesawat udara yang terdiri atas; kebisingan tingkat I, tingkat II dan tingkat III, jika dilihat dari faktor indek kebisingan tersebut maka dapat dipastikan bahwa seluruh lingkungan bandar udara di Indonesia berada pada kebisingan tingkat III atau kawasan dengan nilai indek kebisingan pesawat udara tertinggi yaitu lebih besar atau sama dengan 80 WECPNL (Weighted Equivalent Continuous Perceived Noise Level) atau dapat mencapai lebih dari $84 \mathrm{~dB}$ (Ramita, 2011) (Gambar 3). 


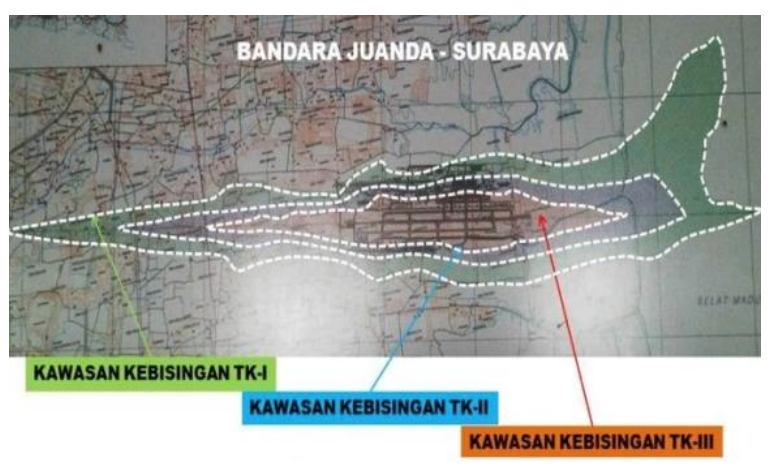

Gambar 3. Kawasan Kebisingan Tingkat I,II, III Bandar udara Juanda Surabaya

Sumber: Kementrian Perhubungan RI, 2002

Landas Pacu (runway), landas hubung (taxiway) dan landas parkir (apron) merupakan lokasi utama aktivitas operasional pesawat terbang yang menjadi sumber utama kebisingan. Kebisingan operasional pesawat terbang mencapai puncaknya pada tahap tinggal landas di lokasi landas pacu yang tekanan suaranya dapat mencapai 135 dB (N.K.Garg, 2007).

Alasan kenyamanan maka suatu gedung diharapkan dapat mengisolasi suara yang datang dari lingkungan sekelilingnya, seperti pada sejumlah gedung di kawasan Bandar udara Juanda Surabaya yang berlokasi di area yang memiliki resiko terkena dampak kebisingan operasional pesawat terbang. Konstruksi gedung tersebut secara umum berupa konstruksi gedung perkantoran pemerintah dimana dengan melihat jenis konstruksi dan material yang dipergunakan maka pada dasarnya gedung tersebut tidak untuk dipersiapkan sebagai bangunan yang dapat menahan dampak kebisingan yang berlebih, bukaan bangunan seperti pada jendela, kisi-kisi ventilasi, shaft jaringan peralatan mekanikal dan elektrikal merupakan titik lemah masuknya kebisingan ke dalam ruang bangunan, prosentase bukaan yang berupa jendela dan kisikisi ventilasi dinding luar pada gedung administrasi mencapai $60 \%$ dengan arah bukaan jendela sebagian tegak lurus arah jalur rambatan kebisingan dari landas pacu. Demikian juga dalam hal jenis material, penggunaan jendela aluminium dengan panil kaca tunggal tebal rata rata $6 \mathrm{~mm}$ tidak cukup mampu untuk mereduksi suara mesin jet pesawat yang datang dari arah landas pacu (Gambar 4).

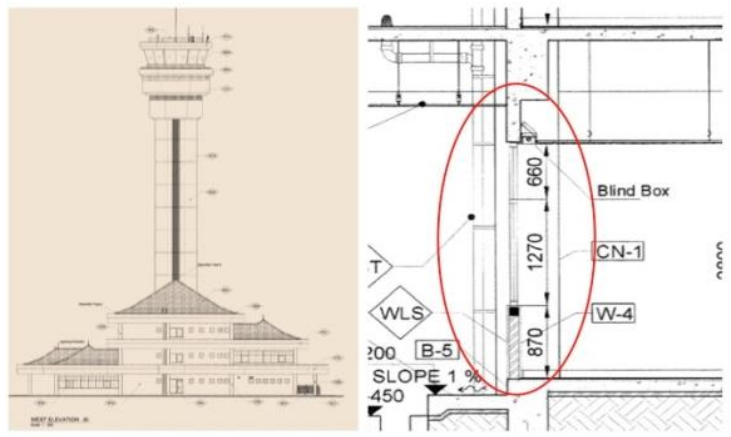

Gambar 4. Gedung Administrasi Bandar udara Juanda

Sumber: Departemen Perhubungan RI, 2007

Melihat kondisi bangunan yang terbatas dalam mereduksi kebisingan dan dengan jarak ke sumber bunyi yang relatif dekat menjadikan ancaman yang serius bagi kesehatan para pekerja yang bertugas di gedung tersebut. Untuk itu dilakukan pengukuran kebisingan untuk 9 gedung fasilitas sisi darat di Bandar udara Juanda, meliputi; gedung terminal penumpang dan kargo, gedung administrasi operasional dan menara pengawas, gedung pompa, DDPU, gedung otorita bandar udara dan gedung VVIP dengan Sound Level Meter SLM-TES52A, dari pengukuran kebisingan tersebut diperoleh nilai intensitas bunyi tertinggi berada pada gedung pompa $(115 \mathrm{~dB})$ dengan jarak dari sumber bising $330 \mathrm{~m}$. Pegukuran intensitas bunyi tersebut juga dapat diketahui bahwa besaran intensitas bunyi atau kebisingan sangat bergantung pada jarak antara bangunan atau fasilitas lain dengan sumber kebisingan bandar udara, jam puncak operasi bandar udara dan jenis pesawat yang beroperasi juga cukup berpengaruh terhadap naiknya nilai intensitas bunyi (Tabel 2).

Tabel 2. Data Survei Kebisingan pada Fasilitas Sisi Darat (Ruang Luar) di Bandar Udara Juanda Surabaya

\begin{tabular}{|l|c|c|c|}
\hline \multicolumn{2}{|c|}{ ACUAN TITIK PENGUKURAN } & NILAI KEBISINGAN (dBA) \\
\hline GEDUNG & JARAK & RATA-RATA & TERTINGGI \\
\hline Gedung terminal penumpang & $615 \mathrm{~m}$ & 99 & 100 \\
Gedung terminal kargo & $440 \mathrm{~m}$ & 105 & 109 \\
Gedung administrasi & $590 \mathrm{~m}$ & 106 & 107 \\
Gedung operasional & $590 \mathrm{~m}$ & 104 & 111 \\
Gedung pompa-1 & $330 \mathrm{~m}$ & 110 & 115 \\
Gedung pompa-3 & $460 \mathrm{~m}$ & 110 & 112 \\
Gedung depo bahan bakar pesawat & $530 \mathrm{~m}$ & 98 & 98 \\
Gedung otorita bandar & $600 \mathrm{~m}$ & 101 & 104 \\
Gedung VVIP & $600 \mathrm{~m}$ & 98 & 98 \\
\hline
\end{tabular}


Gelombang bunyi yang datang pada suatu permukaan yang memisahkan dua area dengan laju gelombang yang berbeda, seperti pada permukaan material kaca, maka gelombang bunyi tersebut sebagian akan dipantulkan dan sebagian lainnya akan diserap atau diteruskan. Bunyi yang datang ke arah gedung adminsitrasi dengan besaran tekanan suara sebesar $111 \mathrm{~dB}$, pada lokasi tersebut dan Nilai Ambang Kebisingan Dalam Gedung adalah 111dB-106 $\mathrm{dB}$ maka perkiraan besaran gelombang yang dipantulkan sebesar $28 \mathrm{~dB}$, bilamana beberapa gelombang pantul tersebut bergabung dengan gelombang datang maka besaran kebisingan pada lingkungan gedung administrasi akan meningkat. Gedung adminsitrasi banyak digunakan untuk aktivitas pengelolaan manajemen bandar udara sehingga diharapkan toleransi kebisingan di dalam ruangan tidak melebihi $65 \mathrm{~dB}$ yang merupakan nilai ambang kenyamanan bekerja dalam ruang kantor dan di luar ruangan tidak lebih dari $85 \mathrm{~dB}$ sebagai nilai ambang kesehatan pekerja (Tabel 3).

Tabel 3. Data Survei Kebisingan Pada Ruangan Fasilitas Sisi Darat (Ruang Dalam) di Bandar Udara Juanda

\begin{tabular}{|l|c|c|c|}
\hline \multicolumn{2}{|c|}{ ACUAN TITIK PENGUKURAN } & \multicolumn{1}{c|}{ NILAI KEBISINGAN (dBA) } \\
\hline GEDUNG & JARAK & RATA-RATA & TERTINGGI \\
\hline Gedung terminal penumpang & $615 \mathrm{~m}$ & 75 & 78 \\
Gedung terminal kargo & $440 \mathrm{~m}$ & 83 & 85 \\
Gedung administrasi & $590 \mathrm{~m}$ & & \\
Gedung operasional & $590 \mathrm{~m}$ & 75 & 76 \\
Gedung pompa-1 & $330 \mathrm{~m}$ & 86 & 87 \\
Gedung pompa-3 & $460 \mathrm{~m}$ & 85 & 85 \\
Gedung depo bahan bakar pesawat & $530 \mathrm{~m}$ & 76 & 76 \\
Gedung otorita bandar & $600 \mathrm{~m}$ & 78 & 79 \\
Gedung VVIP & $600 \mathrm{~m}$ & 74 & 75 \\
\hline
\end{tabular}

Khusus gedung administrasi dilakukan dengan menetapkan landas pacu sebagai sumber kebisingan utama. Pada gedung administrasi, intensitas bunyi cenderung lebih besar pada lantai 1 dan lantai 2 jika dibandingkan dengan lantai ground, hal ini dimungkinkan karena adanya penghalang landscape pada lantai ground, demikian juga ruangan yang berhadapan langsung dengan sumber kebisingan cenderung memiliki intensitas bunyi yang lebih tinggi jika dibandingkan pada ruang sebaliknya atau menghadap ke bagian sisi darat (Tabel 4).
Tabel 4. Data Survei Kebisingan (Ruang Dalam) Gedung Administrasi Udara Juanda Surabaya

\begin{tabular}{|c|c|c|c|c|c|}
\hline \multicolumn{6}{|c|}{ GEDUNG ADMINISTRASI BANDARA JUANDA } \\
\hline \multirow{2}{*}{ LT. } & \multirow{2}{*}{ NAMA RUANG } & \multicolumn{3}{|c|}{ NILAI SLM (dB) } & \multirow{2}{*}{ КЕт. } \\
\hline & & $05.00-12.00$ & 12.00-18.00 & 18.00-24.00 & \\
\hline \multirow[t]{2}{*}{ GF } & RUANG -1 (OFFICE PERSONEL) & 83,40 & 83,30 & 83,30 & 13/11/2016 \\
\hline & RUANG -2 (OFFICE ADMINISTRATION) & 40,20 & 40,40 & 40,10 & 13/11/2016 \\
\hline \multirow[t]{2}{*}{ LT.1 } & RUANG -3 (OFFICE ACCOUNTING) & 86,10 & 86,30 & 86,20 & 14/11/2016 \\
\hline & RUANG -4 (DRAWING ROOM) & 42,40 & 42,50 & 42,40 & 14/11/2016 \\
\hline \multirow[t]{2}{*}{ LT.2 } & RUANG -5 (OFFICE NON AERONOTICAL REV.) & 86,60 & 39,70 & 39,50 & 15/11/2016 \\
\hline & RUANG - 6 (WORKSHOP) & 42,70 & 42,70 & 42,60 & 15/11/2016 \\
\hline
\end{tabular}

Dengan asumsi unit jendela kaca sebagai satu satunya bukaan pada ruang gedung fasilitas sisi darat dan faktor material interior diabaikan, maka perbandingan nilai intensitas ruang pada lingkungan gedung (eksterior) dengan nilai intensitas gedung pada ruang dalam (interior) dapat memberi gambaran secara umum kemampuan unit jendela kaca eksisting dalam mereduksi rambatan bunyi (Tabel 5).

Tabel 5. Data Kemampuan Proteksi Unit Jendela Kaca Eksisting pada Fasilitas Sisi Darat di Bandar Udara Juanda

\begin{tabular}{|l|c|c|c|}
\hline \multirow{2}{*}{ ACUAN TITIK PENGUKURANGEDUNG } & \multicolumn{2}{c|}{ NILAI KEBISINGAN (dBA) } & KEMAMPUAN \\
\cline { 2 - 3 } & R.LUAR & R. DALAM & PROTEKSI \\
\cline { 2 - 3 } 1 Gedung terminal penumpang & 99 & 75 & 24 \\
\hline 2 Gedung terminal kargo & 105 & 83 & 21 \\
\hline 3 Gedung administrasi & $\mathbf{1 0 6}$ & $\mathbf{8 6}$ & $\mathbf{2 0}$ \\
\hline 4 Gedung operasional & 104 & 75 & 28 \\
5 Gedung pompa-1 & 110 & 86 & 24 \\
\hline 6 Gedung pompa-3 & 110 & 85 & 25 \\
\hline 7 Gedung depo bahan bakar pesawat & 98 & 76 & 22 \\
\hline 8 Gedung otorita bandar & 101 & 78 & 23 \\
\hline 9 Gedung VVIP & 98 & 74 & 23 \\
\hline 10 setandar ambang kesehatan & 85 & 65 & \\
\hline
\end{tabular}

\section{RANCANGAN UNIT JENDELA KACA}

Penggunaan desain yang tepat pada rancangan unit bukaam contohnya jendela kaca bangunan merupakan faktor penentu dalam hal mencapai nilai kenyamanan intensitas bunyi ruangan yang diharapkan, standar baku mutu kebisingan untuk perkatoran pada umumnya 65dB (Kusumaatmadja,1996). Mengambil Gedung Administrasi di Bandar udara Juanda Surabaya sebagai studi kasus maka dapat dilakukan analisa rancangan insulasi bunyi pada kawasan dan komponen arsitektur bangunan yaitu unit jendela kaca. 
Pengontrolan jalur transmisi bunyi yang bersumber dari mesin jet pesawat terbang pada dasarnya dapat dilakukan secara skala besar yaitu dengan mengontrol jalur transmisi bunyi pada kawasan dan pada skala yang lebih kecil adalah mengontrol jalur transmisi bunyi yang terjadi pada komponen bangunan seperti unit jendela kaca. Jalur transmisi bunyi pada kawasan bandar udara dapat dikontrol dengan beberapa cara yaitu menghindari peletakan gedung pada jalur landas pacu, menghindari peletakan gedung pada jalur arah tiupan angin pada jalur sumber bunyi, menghindari posisi gedung yang berhadapan secara langsung atau tegak lurus terhadap lokasi sumber kebisingan, penanaman rumput yang mengisi ruang terbuka diantara lokasi sumber suara landas pacu dengan fasilitas sisi darat seperti gedung dapat mereduksi bunyi sampai dengan $5 \mathrm{~dB}$ (Horojeff,1994)

Rancangan insulasi suara pada suatu gedung seperti gedung perkantoran pada dasarnya merupakan upaya perlindungan pendengar atau pekerja secara masal, dengan berfungsinya sistem insulasi bunyi pada gedung tersebut diharapkan akan menurunkan tingkat kebisingan yang diterima pendengar sampai dengan standar ambang batas kesehatan maupun kenyamanan baik pada lingkungan bangunan maupun ruang kerja. Sistem insulasi bunyi yang dapat diterapkan pada keseluruhan unsur gedung yaitu: lantai, dinding, pintu, jendela dan atap termasuk plafond, bukaan gedung pada dinding seperti unit jendela kaca merupakan satu bentuk bukaan yang dapat dioptimalkan fungsi insulasinya, dan tingkat kebisingan itu sendiri ditentukan oleh besaran gelombang bunyi yang datang dan kemampuan kita mengontrol pada jalur transmisinya (Gambar 5).

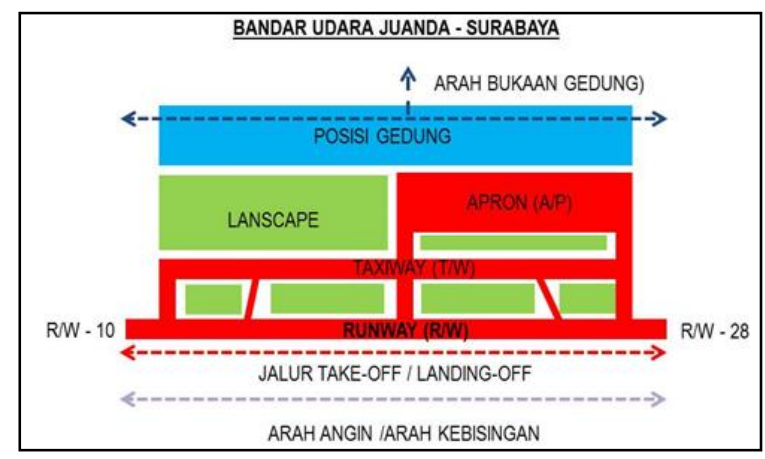

Gambar 5. Posisi Gedung Terhadap Sumber Bunyi

1. Jarak Bangunan
Bunyi merambat melalui jalur (Davis,2008), sehingga jarak rambatan menjadi faktor penentu besaran intensitas bunyi yang diterima oleh pendengar. Data survei menunjukkan bahwa besaran intensitas bunyi di sekitar Gedung Administrasi adalah 106 $\mathrm{dB}$ pada jarak $590 \mathrm{~m}$ dari landas pacu sebagai sumber kebisingan utama, posisi gedung tidak pada jalur tinggal landas pacu ataupun mendarat, demikian juga posisi gedung juga tidak pada arah tiupan angin dari landas pacu, tetapi dalam hal arah rambatan kebisingan maka gedung administrasi berada pada posisi tegak lurus terhadap landas pacu. Dengan memperhatikan kondisi di atas dan ketentuan Master Plan Bandar udara, maka hal-hal yang masih dapat dilakukan adalah ; meminimalisir jumlah bukaan gedung pada sisi arah datangnya sumber kebisingan, menghitung kembali komposisi desain unit jendela kaca yang ada pada sisi tersebut dan memaksimalkan unsur lanscape untuk mengisi celah ruang antara gedung dengan sumber bising.

2. Penentuan Dimensi dan Sudut Unit Jendela Kaca

Dimensi kaca yang digunakan pada sebagian besar gedung di Bandar udara Juanda adalah hag titend glass $6 \mathrm{~mm}$ yang diproduksi oleh pabrikan nasional PT. Asahimas Flat Glass, sesuai spesifikasi pabrikan maka kemampuan reduksi kaca tersebut adalah $25 \mathrm{~dB}$ pada dimensi minimal lebar $(\mathrm{L})=0,5 \mathrm{~m}$ dan tinggi $(\mathrm{H})=3-4 \mathrm{~m}$. Berdasarkan data survei menunjukkan deviasi besaran intensitas bunyi antara ruang luar dan ruang dalam di Gedung Administrasi minimal $28 \mathrm{~dB}$ dengan capaian intensitas bunyi dalam ruang $78 \mathrm{~dB}$ atau masih dibawah standar kenyamanan yang diharapkan yaitu $65 \mathrm{~dB}$. Sejumlah pabrikan kaca merekomendasikan material kacanya datarnya dengan berbagai kemampuan, efektifitas pengurangan kebisingan rata-rata $24,5 \mathrm{~dB}$ untuk kaca 6 mm tunggal dan $29 \mathrm{~dB}$ untuk kaca $2 \times 6 \mathrm{~mm}$. Dengan pertimbangan eisiensi dan untuk mendapatkan angka toleransi keamanan, maka rancangan unit jendela kaca pada Gedung Terminal menggunakan titend glass $6 \mathrm{~mm}$ doble glassing $(2 \times 6 \mathrm{~mm})$.

3. Bahan dan Material

Dengan mengacu pada sifat bunyi yang dapat dibelokan dan diserap (Davis,2008), maka permasalahan kenaikan nilai kebisingan 
akibat pantulan bunyi pada gedung administrasi dapat dicegah dengan melakukan pembelokan dan penyerapan gelombang bunyi pantul tersebut. Unit jendela kaca atau panil kaca akan diposisiskan pada sudut $5^{\circ}$ sehingga jalur gelombang bunyi pantul dapat dibelokan ke arah bagian plafond yang telah dilengkapi dengan material rockwool sebagai penyerap bunyi. Material PVC atau sejenisnya merupakan material yang lebih efektif dalam mereduksi bunyi, menjadikan jenis material tersebut cukup tepat untuk dimanfaatkan dalam rancangan konstruksi utama (rangka) unit jendela, selain faktor ketahanannya terhadap cuaca menjadi nilai positif lainnya.

4. Model Desain Unit Jendela Kaca

Rancangan desain unit jendela kaca dengan material PVC sebagai konstruksi rangka utama dan dimensi panil kaca 2 x $6 \mathrm{~mm}$ serta sudut kemiringan sudut $5^{\circ}$, diharapkan mampu untuk mereduksi kebisingan di dalam gedung administrasi mencapai standar kenyamanan ruang kerja yang dipersaratkan yaitu maksimal $65 \mathrm{~dB}$.

\section{PENGUJIAN ALTERNATIF RANCANGAN}

Pengujian alternatif rancangan terutama akan dilakukan terhadap desain unit jendela kaca pada gedung administrasi bandar udara, sementara untuk modifikasi sumber bunyi dan modifikasi jalur transmisi bunyi pada kesempatan pembahasan ini tidak dilakukan pengujian karena beberapa hal bersifat peraturan dan kebijakan pemerintah secara nasional. Hasil rancangan desain unit jendela kaca yang didasarkan pada data perimer dan sekunder akan diperhitungkan kembali atau diuji secara matematis dengan mengacu ketentuan N.K. Garg, sehingga hasil keduanya akan diperbandingkan untuk kemudian di analisa dan simpulkan sekaligus sebagai rekomendasi rancangan.

Dalam perhitungan N.K. Garg maka faktor-faktor yang akan mempengaruhi tekanan suara atau kebisingan di dalam bangunan adalah besar bising sumber, jarak transmisi bunyi, barier atau penghalang antar sumber bunyi dan bangunan dan jenis serta dimensi material pemisah ruang luar dan dalam bangunan, ketentuan tersebut dituliskan dalam persamaan
MNL (Modified Noise Level) $=$ NLS $-20 \log 10$ $\mathrm{r}-10.9$ dan INL (Inside Noise Level) $=$ ANL $\mathrm{Rw}+\log 10 \mathrm{~s}$.

Sebagai data umum guna pengujian unit jendela kaca pada sejumlah bangunan termasuk gedung administrasi di kawasan Bandar Udara Juanda dapat ditunjukan pada Tabel 6.1 dan Tabel 6.2, pada tabel tersebut dijelaskan sebagian gedung utama yang berada di kawasan Bandar udara Juanda dengan sejumlah faktor yang akan mempengaruhi intensitas bunyi baik pada lingkungan gedung maupun pada ruang dalam dari gedung tersebut, faktor dimaksud adalah jarak sumber bunyi yang dalam hal ini mengacu sebagai titik utama pada landas pacu sebagai lokasi sumber bunyi utama, serta faktor lainnya adalah barier dan dimensi kaca eksisting gedung tersebut (Tabel 6, dan 7).

Tabel 6. Data Eksisting Jarak Gedung

\begin{tabular}{|c|c|c|c|}
\hline \multirow{2}{*}{ GEDUNG } & \multirow{2}{*}{$\begin{array}{c}\text { JARAK } \\
\text { DNG } \\
\text { R/W }\end{array}$} & \multicolumn{2}{|c|}{ BARIER } \\
\hline & & JENIS & NILAI \\
\hline $\begin{array}{l}\text { Passenger term. } \\
\text { build. }\end{array}$ & $615 \mathrm{~m}$ & Lanscape & $5 \mathrm{~dB}$ \\
\hline Cargo building & $440 \mathrm{~m}$ & Lanscape & $5 \mathrm{~dB}$ \\
\hline $\begin{array}{l}\text { Operasional \& } \\
\text { Administrasi }\end{array}$ & $590 \mathrm{~m}$ & Lanscape & $5 \mathrm{~dB}$ \\
\hline Pump house - 1 & $330 \mathrm{~m}$ & $\begin{array}{l}\text { Reg. } \\
\text { Ponding }\end{array}$ & $5 \mathrm{~dB}$ \\
\hline Pump house - 3 & $460 \mathrm{~m}$ & $\begin{array}{l}\text { Reg. } \\
\text { Ponding }\end{array}$ & $5 \mathrm{~dB}$ \\
\hline $\begin{array}{ll}\text { Fuel supply } \\
\text { building }\end{array}$ & $530 \mathrm{~m}$ & $\begin{array}{l}\text { Jalan } \\
\text { inspeksi }\end{array}$ & $3 \mathrm{~dB}$ \\
\hline $\begin{array}{l}\text { Otoritas bandar } \\
\text { udara }\end{array}$ & $600 \mathrm{~m}$ & Lanscape & $5 \mathrm{~dB}$ \\
\hline VVIP building & $660 \mathrm{~m}$ & GSE & $3 \mathrm{~dB}$ \\
\hline
\end{tabular}

Tabel 7. Data Eksisting Jarak Gedung

\begin{tabular}{|c|c|c|c|}
\hline \multirow[b]{2}{*}{ GEDUNG } & \multicolumn{3}{|c|}{ NOISE REDUCTION INDEX } \\
\hline & $\begin{array}{l}\text { JENIS } \\
\text { KACA }\end{array}$ & $\begin{array}{l}\text { NILAI } \\
\text { INDEX }\end{array}$ & $\begin{array}{l}\text { MASSA } \\
(\text { Kg/M2) }\end{array}$ \\
\hline $\begin{array}{l}\text { Passenger } \\
\text { term. build. }\end{array}$ & $\begin{array}{c}6 \mathrm{~mm} \\
\text { tinted glass }\end{array}$ & 31 & 130 \\
\hline Cargo building & $\begin{array}{c}6 \mathrm{~mm} \\
\text { tinted glass }\end{array}$ & 31 & 130 \\
\hline $\begin{array}{l}\text { Operasional \& } \\
\text { Administrasi }\end{array}$ & $\begin{array}{c}6 \mathrm{~mm} \\
\text { tinted glass }\end{array}$ & 31 & 130 \\
\hline Pump house - 1 & $\begin{array}{c}6 \mathrm{~mm} \\
\text { tinted glass }\end{array}$ & 31 & 130 \\
\hline Pump house - 3 & $\begin{array}{c}6 \mathrm{~mm} \\
\text { tinted glass }\end{array}$ & 31 & 130 \\
\hline $\begin{array}{l}\text { Fuel supply } \\
\text { building }\end{array}$ & $\begin{array}{c}6 \mathrm{~mm} \\
\text { tinted glass }\end{array}$ & 31 & 130 \\
\hline $\begin{array}{l}\text { Otoritas bandar } \\
\text { udara }\end{array}$ & $\begin{array}{c}8 \mathrm{~mm} \\
\text { tinted glass }\end{array}$ & 32 & 173 \\
\hline VVIP building & $\begin{array}{c}8 \mathrm{~mm} \\
\text { tinted glass }\end{array}$ & 32 & 173 \\
\hline
\end{tabular}


Mengacu ketentuan N.K. Garg, faktor penentu besaran nilai intensitas bunyi diantaranya adalah jarak sumber bunyi dan jenis penghalang, kedua faktor tersebut dapat dimodifikasi guna menurunkan nilai intensitas bunyi sampai dengan level tertentu. Jarak sumber bunyi pada kawasan bandar udara yang telah beroperasi pada dasarnya relatif sulit untuk dilakukan modifikasi jarak sumber bunyi dimaksud karena susunan fasilitas bandar udara yang berupa layout bandar udara telah mengacu pada ketentuan dan perhitungan tertentu. Jika memungkinkan adanya modifikasi terhadap jarak sumber bunyi dari fasilitas bandar udara maka pengujian melalui perhitungan (Tabel 8, dan 9) menunjukkan hasil kebutuhan jarak yang diperlukan guna menurunkan intensitas suara sampai dengan level yang diharapkan untuk kenyamanan ruang atau perlindungan kesehatan karyawan.

Tabel 8. Modifikasi Jarak Sumber Bunyi (Modified Noise Level)

\begin{tabular}{|c|c|c|c|c|c|c|c|}
\hline NO. & GEDUNG & NLS & $(r)$ & MNL & \multicolumn{2}{|c|}{$\begin{array}{c}\text { BARIER (dB) } \\
(B R)\end{array}$} & $\begin{array}{l}\text { MNL } \\
\text { - BR } \\
(\mathrm{dB})\end{array}$ \\
\hline 1 & Passenger terminal building & 135 & 19.4 & 99 & 5 & Lanscape & 94 \\
\hline 2 & Cargo building & 135 & 19.4 & 99 & 5 & Lanscape & 94 \\
\hline 3 & Administrasi & 135 & 19.4 & 99 & 5 & Lanscape & 94 \\
\hline 4 & Operasional & 135 & 19.4 & 99 & 5 & Lanscape & 94 \\
\hline 5 & Pump house - 1 & 135 & 19.5 & 99 & 5 & Reg. Ponding & 94 \\
\hline 6 & Pump house - 3 & 135 & 19.4 & 99 & 5 & Reg. Ponding & 94 \\
\hline 7 & Fuel supply building & 135 & 21 & 97 & 3 & Jalan inspeksi & 94 \\
\hline 8 & Otoritas bandara & 135 & 19.4 & 99 & 5 & Lanscape & 94 \\
\hline 9 & VIP building & 135 & 21 & 97 & 3 & GSE & 94 \\
\hline $\begin{array}{l}\text { KET: } \\
\text { - NLS } \\
-r \\
- \text { - MNL }\end{array}$ & $\begin{aligned}= & \text { NOISE LEVER (dB) AT SOL } \\
= & \text { DISTANSE OF THE BUILD } \\
= & \text { MODIFIED NL(dB) } \\
& (\text { NLS }-20 \log 10 \mathrm{r}-10.9)\end{aligned}$ & & & & & & \\
\hline
\end{tabular}

Tabel 9. Modifikasi Jarak Sumber Bunyi (Inside Noise Level)

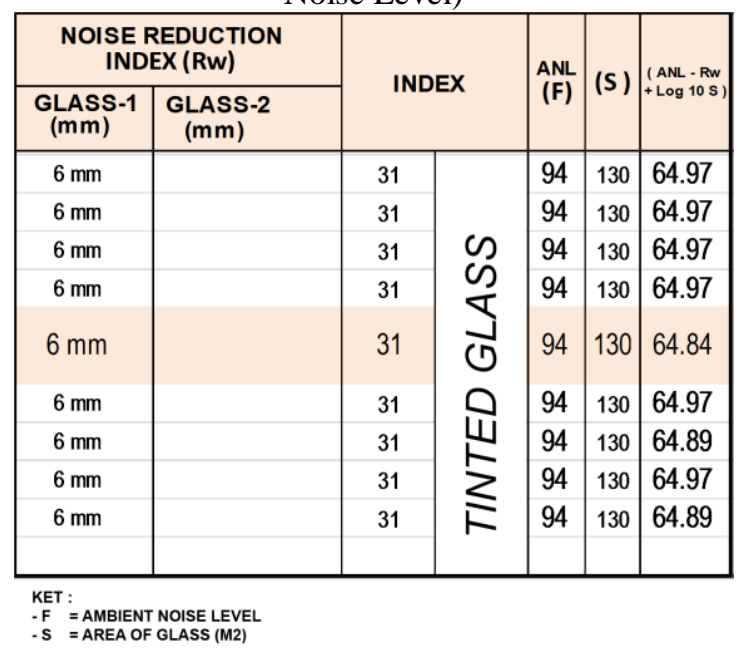

Asumsi penggunaan material dan dimensi penghalang yang sama (tinted glass $6 \mathrm{~mm}$ ) dan besaran intensitas sumber bunyi yang juga sama, maka jarak yang diperlukan untuk gedung administrasi sehingga dihasilkan intensitas bunyi yang memenuhi standar kenyamanan ruang kerja $(<65 \mathrm{~dB})$ adalah $19.400 \mathrm{~m}$ dari jarak awal atau eksisting $590 \mathrm{~m}$, demikian hal yang sama untuk semua gedung fasilitas bandar udara lainnya.

Selain faktor jarak tersebut diatas, maka jenis penghalang transmisi bunyi seperti kaca pada jendela gedung juga dapat menentukan besaran intensitas bunyi yang masuk kedalam ruang yang ada. Dalam rangka pengujian terhadap konsep rancangan unit jendela kaca pada gedung administrasi melalui perhitungan matematis N.K. Garg, maka selain akan diuji unit jendela kaca dengan dimensi 2x6mm seperti pada konsep rancangan, pengujian juga akan dilakukan untuk sejumlah dimensi kaca baik sistem kaca tunggal yaitu dimensi $6 \mathrm{~mm}$, $8 \mathrm{~mm}$ dan $10 \mathrm{~mm}$, maupun kaca ganda (double glass) yaitu dimensi $2 \times 6 \mathrm{~mm}, 2 \times 8 \mathrm{~mm}, 2 \times 10 \mathrm{~mm}$, $6 \mathrm{~mm}-8 \mathrm{~mm}, 6 \mathrm{~mm}-10 \mathrm{~mm}$ dan $8 \mathrm{~mm}-10 \mathrm{~mm}$, hasil perhitungan.

Untuk mencapai target mutu kebisingan di gedung administrasi Bandar udara Juanda maupun sejumlah gedung lainnya, maka konsep desain pada unit jendela kaca dengan tujuan untuk lebih mereduksi kondisi kebisingan di dalam ruangan seperti yang telah dijelaskan pada bab empat yaitu konsep rancangan, maka berdasarkan data uji matematis diatas menunjukan bahwa pemanfaatan unit jendela dengan kaca ganda secara umum menghasilkan nilai hambatan atau insulasi bunyi yang lebih efesien bagi keseluruhan gedung di Bandar udara Juanda Suarabaya, penggunaan unit jendela kaca ganda $2 \times 6 \mathrm{~mm}$ (minimal dimensi) pada gedung administrasi mampu menghasilkan nilai insulasi bunyi sebesar $54 \mathrm{~dB}$, sehingga desain rancangan unit jendela dengan memanfaatkan sistem kaca ganda dan berdasarkan perhitungan matematis N.K.Garg tersebut secara umum dapat dimanfaatkan untuk mengatasi kondisi kebisingan ruang dalam pada keseluruhan gedung di Bandar udara Juanda Suarabaya (Gambar 6). 


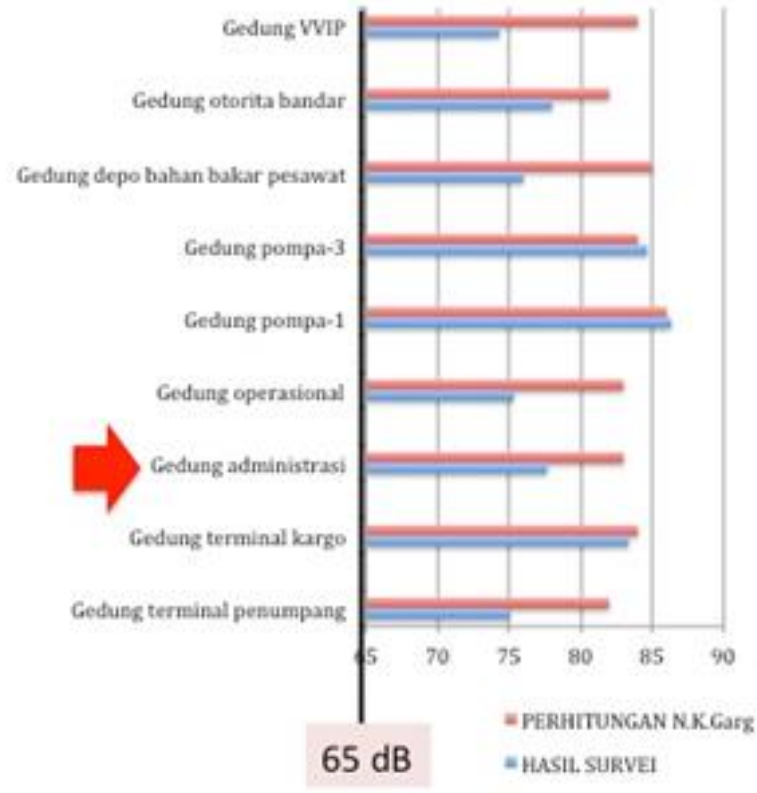

Gambar 6. Bharchart Perbandingan Nilai Kebisingan (dBA) pada Ruang Dalam Gedung di Bandar udara Juanda

Melihat perbandingan data yang sama yaitu data berdasarkan survey (rancangan desain) dan berdasarkan perhitungan matematis, maka dapat diketahui juga bahwa kemampuan insulasi dari masing masing unit kaca tersebut, nilai insulasi kaca eksisting berdasarkan survei adalah $28 \mathrm{~dB}$ pada gedung administrasi dan 24 $\mathrm{dB}$ rata-rata pada gedung lainnya, sementara dari perhitungan matematis kemampuan insulasi kaca tersebut dapat ditingkatkan secara signifikan jika menggunakan system kaca ganda, perhitungan matematis pada kaca ganda 2 x $6 \mathrm{~mm}$ pada gedung administrasi menghasilkan kemampuan insulasi sebesar 57 $\mathrm{dB}$ dan rata-rata gedung lainnya sebesar $58 \mathrm{~dB}$, sementara berdasarkan data survei diperlukan kemampuuan mereduksi dari unit jendela kaca minimal sebesar $41 \mathrm{~dB}$ untuk mencapai lingkungan ruang kerja yang nyaman, perbandingan kemampuan insulasi (Gambar 7).

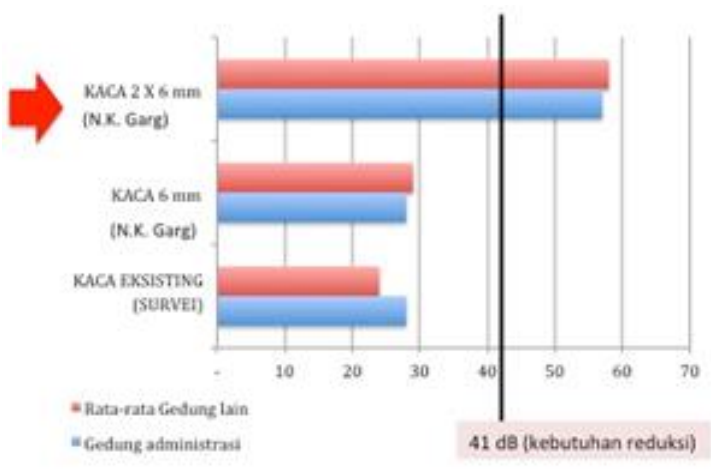

Gambar 7. Bharchart Perbandingan Kemampuan Insulasi Kaca (dBA) pada Gedung di Bandar udara Juanda

Dari keseluruhan perbandingan data terkait insulasi kebisingan di atas maka dapat disimpulkan bahwa konsep desain unit jendela kaca dengan memanfaatkan kaca ganda dengan berbagai variasi dimensinya dapat dimanfaatkan guna mengatasi permasalahan kebisingan pada sejumlah gedung yang ada di kawasan Bandar udara.

Mengacu pada sifat bunyi yang dapat dibelokan dan diserap (Davis,2008), maka permasalahan kenaikan nilai MNL akibat pantulan bunyi pada gedung administrasi dapat dicegah dengan melakukan pembelokan dan penyerapan gelombang bunyi pantul tersebut, modifikasi posisi panil kaca pada unit jendela kaca dengan sudut tertentu diharapkan mampu membelokan arah bunyi pantul ke permukaan dinding unit jendela yang telah dilengkapi dengan material penyerap bunyi.

Hukum pantulan bunyi atau cahaya Snellius menyatakan bahwa sudut datang persis sama dengan sudut pantul (Abdullah, 2006), dari ketentuan tersebut maka panil kaca pada unit jendela kaca perlu diposisiskan pada sudut yang tepat sehingga jalur gelombang bunyi pantul dapat dibelokan ke arah yang dituju. Terdapat empat alternativ arah pemantulan gelombang bunyi yaitu ke atas menuju plafon bangunan, ke bawah menuju lantai bangunan untuk arah vertikal dan ke kanan atau kiri menuju dinding bangunan untuk arah horisontal (gambar 19). Keempat arah pemantulan gelombang bunyi tersebut dapat dilakukan, tetapi dengan pertimbangan bahwa gelombang bunyi yang dipantulkan harus dapat diserap maka arah vertikal yaitu menuju plafon ataupun lantai dinilai lebih efektif untuk dilakukan. 
Selain faktor arah maka besarnya sudut pantul akan menentukan besaran radius gelombang bunyi sekaligus luas area penyerapan yang harus disediakan, penentuan sudut penempatan panil kaca juga perlu memperhatikan desain unit jendela kaca yang ada. Dengan asumsi tinggi jendela kaca 0,9 meter (bawah) dan 2,95 meter (atas), tinggi plafon 3,2 meter, panjang teras atau lobby luar 4 meter, maka penempatan sudut panil kaca dapat dijelaskan pada Gambar 8, 9 dan Tabel $10,11,12$. Sudut $15^{\circ}$ untuk panil kaca pada unit jendela cukup ideal untuk membelokan atau memantulkan bunyi ke arah plafon dengan lebar area serapan mencapai panjang 4 meter. Tindakan untuk mengontrol gelombang bunyi yang diakibatkan oleh pemantulan diharapkan dapat mereduksi kebisingan terutama yang terjadi di lingkungan gedung.

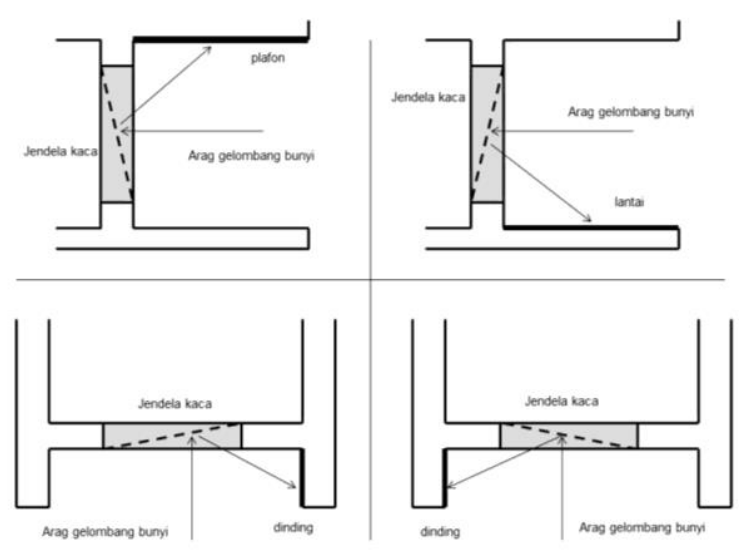

Gambar 8. Arah Pemantulan Gelombang Bunyi

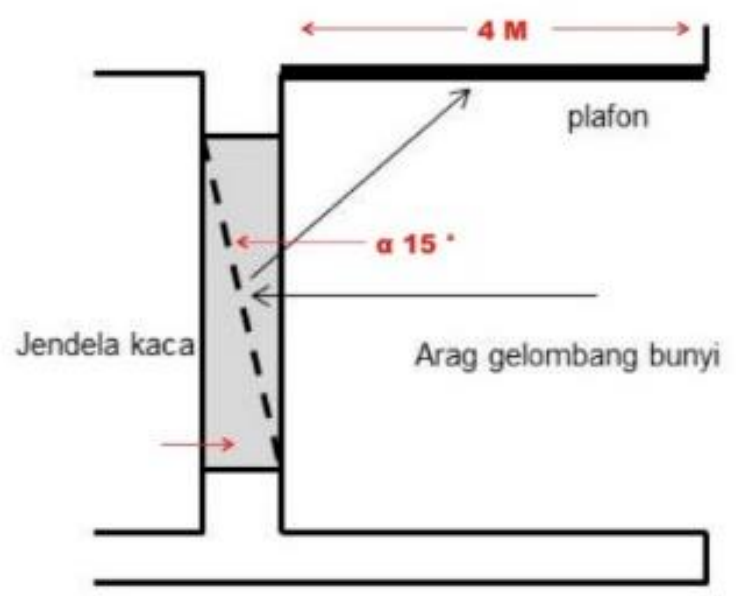

Gambar 9. Alternatif Arah Pemantulan Gelombang Bunyi
Tabel 10. Kemampuan Proteksi Kebisingan pada Kaca Tunggal

\begin{tabular}{|l|l|l|l|}
\hline \multicolumn{1}{|c|}{$\begin{array}{c}\text { ACUAN TITIK PENGUKURAN } \\
\text { GEDUNG }\end{array}$} & \multicolumn{3}{c|}{ NILA KEBIINGAN (dBA) KACA TUNGGAL } \\
\cline { 1 - 2 } & $6 \mathrm{MM}$ & $8 \mathrm{MM}$ & $\mathbf{1 0} \mathrm{MM}$ \\
\hline 1 Gedung terminal penumpang & 82 & 81 & 80 \\
\hline 2 Gedung terminal kargo & 84 & 84 & 83 \\
\hline 3 Gedung administrasi & 83 & 82 & 81 \\
\hline 4 Gedung operasional & 83 & 82 & 81 \\
\hline 5 Gedung pompa-1 & 86 & 85 & 84 \\
\hline 6 Gedung pompa-3 & 84 & 83 & 82 \\
\hline 7 Gedung depo bahan bakar pesawat & 85 & 84 & 84 \\
\hline 8 Gedung otorita bandar & 82 & 82 & 81 \\
\hline 9 Gedung WVIP & 84 & 83 & 82 \\
\hline 10 setandar ambang kesehatan & 65 & & \\
\hline
\end{tabular}

Tabel 11. Kemampuan Proteksi Kebisingan pada Kaca Ganda

\begin{tabular}{|c|c|c|c|}
\hline \multirow{2}{*}{$\begin{array}{c}\text { ACUAN TITIK PENGUKURAN } \\
\text { GEDUNG }\end{array}$} & \multicolumn{3}{|c|}{ NIILA KEBISINGAN (dBA) KACA GANDA } \\
\hline & $2 \times 6 \mathrm{MM}$ & $2 \times 8 \mathrm{MM}$ & $2 \times 10 \mathrm{MM}$ \\
\hline 1 Gedung terminal penumpang & 53 & 52 & 50 \\
\hline 2 Gedung terminal kargo & 56 & 54 & 52 \\
\hline 3 Gedung administrasi & 54 & 52 & 50 \\
\hline 4 Gedung operasional & 54 & 52 & 50 \\
\hline 5 Gedung pompa-1 & 57 & 55 & 53 \\
\hline 6 Gedung pompa-3 & 55 & 54 & 52 \\
\hline 7 Gedung depo bahan bakar pesawat & 56 & 55 & 53 \\
\hline 8 Gedung otorita bandar & 54 & 52 & 50 \\
\hline 9 Gedung WIP & 55 & 53 & 51 \\
\hline 10 setandar ambang kesehatan & 65 & & \\
\hline
\end{tabular}

Tabel 12. Kemampuan Proteksi Kebisingan pada Kaca Ganda

\begin{tabular}{|c|c|c|c|}
\hline \multirow{2}{*}{$\begin{array}{c}\text { ACUAN TITIK PENGUKURAN } \\
\text { GEDUNG }\end{array}$} & \multicolumn{3}{|c|}{ NILA KEBISINGAN (dBA) KACA GANDA } \\
\hline & $6 \times 8 \mathrm{~mm}$ & $6 \times 10 \mathrm{~mm}$ & $8 \times 10 \mathrm{~mm}$ \\
\hline & 52 & 52 & 51 \\
\hline 2 Gedung terminal kargo & 55 & 55 & 53 \\
\hline 3 Gedung administrasi & 53 & 52 & 51 \\
\hline 4 Gedung operasional & 53 & 52 & 51 \\
\hline 5 Gedung pompa-1 & 56 & 55 & 54 \\
\hline 6 Gedung pompa-3 & 54 & 54 & 53 \\
\hline 7 Gedung depo bahan bakar pesawat & 56 & 55 & 54 \\
\hline 8 Gedung otorita bandar & 53 & 52 & 51 \\
\hline 9 Gedung WIP & 54 & 53 & 52 \\
\hline 10 setandar ambang kesehatan & 65 & & \\
\hline
\end{tabular}

\section{KESIMPULAN}

Nilai ambang batas atau standar faktor tempat kerja yang dapat diterima tenaga kerja tanpa mengakibatkan penyakit atau gangguan kesehatan dalam pekerjaan sehari-hari untuk waktu tidak melebihi 8 jam sehari atau 40 jam seminggu adalah $85 \mathrm{~dB}$ (Idris,1999), sementara untuk baku mutu kebisingan untuk perkantoran pada umumnya 65 dB (Kusumaatmadja,1996). Dari hasil pembahasan mengenai Penurunan Tingkat Kebisingan Ruang Kerja Melalui Optimalisasi Fungsi Jendela Kaca Pada Gedung Administrasi Bandar udara, maka dapat diperoleh kesimpulan: (1) Keseluruhan kawasan Bandar udara Juanda Surabaya masuk dalam 
kawasan kebisingan tingkat III dengan nilai ambang kebisingan di sekitar fasilitas sisi udara dapat mencapai $115 \mathrm{~dB}$, sementara untuk fasilitas sisi darat seperti gedung administrasi nilai ambang kebisingannya mencapai $106 \mathrm{~dB}$ pada ruang luar dan $86 \mathrm{~dB}$ pada ruang dalam. Mengacu pada standar nilai ambang batas kebisingan yang tidak mengganggu kesehatan pekerja yaitu $<85 \mathrm{~dB}$ dan kenyamanan bekerja yaitu < $65 \mathrm{~dB}$, maka salah satu upaya untuk menurunkan intensitas bunyi atau kebisingan tersebut dapat melalui komponen arsitektur gedung seperti unit jendela kaca dengan pemanfaatan sistem kaca ganda; (2) Ruangan dengan bukaan gedung seperti jendela kaca yang berhadapan langsung dengan sumber bunyi cenderung memiliki nilai intensitas bunyi atau kebisingan yang jauh lebih tinggi jika dibandingkan dengan ruangan yang tidak berhadapan langsung sehingga diperlukan penanganan tertentu pada bukaan gedung dimaksud. Pemanfaatan sistem kaca ganda atau double glazing pada unit jendela dapat menaikan nilai insulasi lebih dari $30 \%$, penggunaan kaca ganda minimal 2 x $6 \mathrm{~mm}$ pada unit jendela kaca gedung administrasi dapat mereduksi bunyi sampai dengan nilai ambang kebisingan yang dipersyaratkan yaitu $\leq 65 \mathrm{~dB}$, alternatif tersebut jauh lebih efisien jika dibandingkan dengan memperbesar dimensi atau ketebalan kaca ataupun memodifikasi jarak gedung dari sumber bising. Keberadaan bunyi pantul atau gema pada ruang luar terutama di sekitar dinding penempatan unit jendela kaca yang akan bergabung dengan bunyi asli yang datang dari arah sumber bunyi akan menaikan nilai ambang kebisingan pada lingkungan tersebut, pemasangan unit jendela dengan posisi sudut kemiringan kaca $\pm 15^{\circ}$ dapat membelokan bunyi pantul ke arah permukaan bangunan seperti plafond yang telah dilengkapi dengan pelapisan permukaan yang berpori seperti material rock wool, sehingga dapat terserap secara keseluruhan dan tidak menambah dampak kebisingan pada ruang luar. Disamping terkait desain, maka pemilihan material juga sangat berperan dalam pencapaian nilai akhir kebisingan tersebut, penggunaan material yang memiliki nilai terendah atau negatip terhadap faktor penghantar geteran bunyi seperti kayu dan plastik (PVC) sangat baik untuk dipilih sebagai material penyusun struktur (frame) unit jendela kaca, material tersebut akan meminimalisir efek getaran bunyi yang akan merambat dari bagian luar gedung.

\section{Daftar Pustaka}

Ashford, Norman (1992) Airport Engineering. New York.

Davis, Mackenzie L. (2008) Environmental Engineering.London: McGraw-Hill.

Doelle, Leslie L. (1972) Akustik Lingkungan. Jakarta: Erlangga.

Evi, I.W.Wardana, E.Sutrisno (2013) "Daily Mapping Aircraft Noise Level in Unit Aoron Ahmad Yani Airport, Semarang, Central Jawa, Using Contour Noise Methode" Semarang, Jurnal, Program Pasca Sarjana Universitas Diponegoro

Garg, N.K. (2007) Use of Glass in Building. London: New Age International.

Hukum

Snellius, https://id.wikipedia.org/wiki/Hukum_Snel lius. Diakses 13 Mei 2014

Horojeff, Robert (1994) Planning and Design of Airport. New York: McGraw-Hill.

Idris, Fahmi (1999) Nilai Ambang Batas Faktor Fisika Di Tempat Kerja (Kep.51/MEN/1999). Jakarta: Kementrian Tenaga Kerja RI.

Kusumaatmadja, Sarwono (1996) Baku Tingkat Kebisingan (KEP-48/MENLH/11/1996). Jakarta: Kementrian Lingkungan Hidup RI.

M.Chaeran (2008) "Kajian Kebisingan Akibat Aktivitas di Bandar udara, Studi Kasus Bandar udara Ahmad Yani Semarang", Semarang, Master Thesis, Program Pasca Sarjana Universitas Diponegoro.

Mangindaan, E.E. (2013) Tatanan Kebandarudaraan Nasional (PM No.69 Tahun 2013). Jakarta: Kementrian Perhubungan. 
Peraturan Pemerintah Nomor 40 Tahun 2012 Tentang Pembangunan dan Pelestarian Lingkungan Hidup Bandar Udara.

P.Miroslov, H.Rettob, R.Djajakusli, M.Muis (2013) "Studi Hearing Loss Tenaga Kerja dan Masyarakat di Wilayah Bandar udararajawsa Sultan Hasanuddin Makassar”, Makassar, Jurnal, FKM Universitas Hasanuddin Makassar.

Ramita (2013) Pengaruh Kebisingan dari Aktifitas Bandar udara Internasional Juanda Surabaya. Jurnal Ilmiah Teknik Lingkungan UPN Surabaya.

Yudhoyono, Susilo Bambang. (2012). Pembangunan dan Pelestarian Lingkungan Hindup Bandar Udara (PP NO 40/2012). Jakarta: Pemerintah RI. 